Жорова I. Я., orcid.org/0000-0003-4304-4962 Богданов Є. П. , orcid.org/0000-0002-4559-3052

\title{
ОРГАНІЗАЦІЙНО-МЕТОДИЧНЕ ЗАБЕЗПЕЧЕННЯ ПРОСВІТНИЦЬКОЇ ДІЯЛЬНОСТІ 3 ЦИВІЛЬНОЇ ОБОРОНИ У 80-Х РОКАХ ХХ СТОЯІТТЯ
}

У статті здійснено контент-аналіз основних документів 80-x років XX століття у сфері цุивільної оборони в СРСР, які сприяли здійсненню просвітницьвкої діяльності серед населення (за виключенням закладів освіти).

Акцентовано увагу на виданнях 80-х років ХХ століття, затверджених Міністерством оборони (МО) СРСР та Цивільною обороною (ЦО) СРСР (Положення про курси цุивільної оборони; Комплексні навчання цзиільної оборони на об'єктах народного господарства; Програми пришвидшеної підготовки робітників, колгоспників та службови̨ів до захисту від зброї масового ураження; Програми спецізальної підготовки невоєнізованих формувань цุивільної оборони на об'єктах народного господарства, Інструкції та ін.); Штабів цุивільної оборони республік (Рекомендації з підготовки та проведення об'єктних тренувань з изивільної оборони; Методичні розробки до затвердженого переліку тем тощо), областей (Методичні розробки до проведення групових занять на курсах цъивільної оборони з керівним складом ЦО (організація навчання населення, не зайнятого на виробництві та в сфері обслуговування), Рекомендації до проведення оглядів-конкурсів тощо); посібники на кщталт «Організація іметодика проведення занять з ццивільної оборони з командирами розвідувальних формувань», «Цивільна оборона», «Цивільна оборона (Методичні вказівки до комплекту навчальних плакатів)» тощо. Зауважено, ще видання з цзивільної оборони розповсюджувались усіма державними установами, а їх зміст був обов'язковим для опанування населенням держави, на відміну від сьогодення.

Кожна тема з изивільної оборони передбачала не лише перелік питань для опрацювання, асупроводжувалася методичними вказівками, що допомагало керівнику групи у проведенні занять та уможливлювало стандартизаціюо їх проведення в різних регіонах країни. Наголошено, що кожен слухач вірпацвовуе практичні навички разом із засвоєнням теоретичної інформаціӥ та мае можливість користуватися необхідним матеріальним забезпеченням.

Таким чином, досягнуто мету статті - актуалізация вітчизняного досвіду здійснення просвітницької діяльності серед населення (за виключенням учнівської та студентської молоді) з ицивільної оборони у 80-х роках ХХ століття.

Ключові слова: ццивільна оборона, просвітницька діяльність, курси цุивільної оборони, програми підготовки, методичні розробки.

Постановка проблеми. Питання запобігання катастрофам техногенного характеру, можливим вторгненням (військовій агресії) з боку інших країн, поширенню невідомих раніше хвороб і просвітницька діяльність серед населення щодо готовності до відповідних наслідків не втрачає актуальності багато століть, оскільки, на жаль, поряд із егалітарними змінами в освітній сфері спостерігається масова залежність населення від гаджетів та неспроможність приймати адекватні рішення з наступною відповідальністю за їх наслідки. Просвітницька діяльність серед широких верств населення з тих чи інших питань, вкдючаючи й питання захисту (і самозахисту) від різного роду нападів набула

\footnotetext{
*(C) Жорова I. Я.
}

*C Богданов $Є . \Pi$.

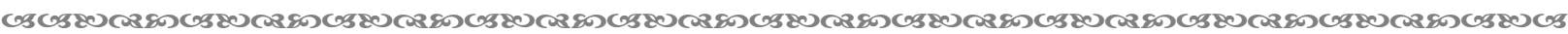
196 
розповсюдження у другій половині XX століття під час так званої «хододної війни» (протистояння СРСР та США), особливо у сфері цивільної оборони (ЦО) (сучасний термін - цивільний захист). Зауважимо, що ця діяльність мала певні продуктивні напрацювання, які доцільно адаптувати до сучасних реалій, оскільки просвітницька діяльність щодо забезпечення самозахисту / самозбереження та забезпечення сталого розвитку суспільства в кризових умовах серед населення у цілому, і молоді зокрема, практично не проводиться. Відбувається лише підготовка вузькопрофільних фахівців у сфері цивільного захисту населення. Тому вважаємо за доцільне актуалізувати окремі аспекти вітчизняного досвіду просвітницької діяльності 80-х років XX століття

Аналіз досліджень. У попередніх авторських напрацюваннях [1;2] окреслено тематичні напрями, за якими здійснюються сучасні дослідження у сфері цивільного захисту, що засвідчидо відсутність наукових розвідок щодо актуадізації питань просвітницької діяльності в період другої половини XX століття у сфері цивільного захисту населення. Тому акцентуємо увагу на виданнях 80-х років XX століття, які склали основу для просвітницької роботи серед населення (без урахування відповідної діяльності в закдадах освіти різних типів і рівнів). Це, зокрема, видання, затверджені Міністерством оборони (МО) СРСР та Цивільною обороною СРСР (Положення про курси цивільної оборони, затверджені відповідними наказами начальника цивільної оборони СРСР - заступника Міністра оборони СРСР; Комплексні навчання цивільної оборони на об'єктах народного господарства; Програми пришвидшеної підготовки робітників, колгоспників та службовців до захисту від зброї масового ураження; Програми спеціальної підготовки невоєнізованих формувань цивільної оборони на об’єктах народного господарства, Інструкції та ін.); Штабів цивільної оборони республік (Рекомендації з підготовки та проведення об'єктних тренувань з цивільної оборони; Методичні розробки до затвердженого переліку тем тощо), областей (Методичні розробки до проведення групових занять на курсах цивільної оборони 3 керівним складом ЦО (організація навчання населення, не зайнятого на виробництві та в сфері обслуговування), Рекомендації до проведення оглядів-конкурсів тощо); посібники (рекомендовані штабом ЦО СРСР або республік, або МО СРСР) на кшталт «Організація і методика проведення занять 3 цивільної оборони 3 командирами розвідувальних формувань», «Цивільна оборона», «Цивільна оборона (Методичні вказівки до комплекту навчальних плакатів)» тощо. Зауважимо, що видання 3 цивільної оборони розповсюджувались усіма державними установами, а їх зміст був обов'язковим для опанування населенням держави. Контроль за рівнем сформованості відповідних знань, умінь і навичок з цивільної оборони було покладено на спеціально створені органи штаби цивільної оборони.

Метою статті визначаємо актуалізацію вітчизняного досвіду здійснення просвітницької діяльності серед населення (за виключенням учнівської та студентської молоді) з цивільної оборони у 80-х роках XX століття.

Виклад основного матеріалу. Для усвідомлення змістової та методичної складових здійснення просвітницької діяльності з цивільної оброни (сучасний термін цивільний захист) населення у період 80-х років XX століття репрезентуемо тогочасні визначення. Цивільна оборона (Ц.О. за всерадянським тлумаченням) - це «система загадьнодержавних заходів, що проводяться для захисту наседення від мождивого повітряного нападу противника та забезпечення сталої роботи народного господарства. У 50-60-pp. XX століття створена у більшості крупних держав, наявні спеціальні органи управдіння Ц. О., війська, воєнізовані та невоєнізовані формування 3 працездатного населення» [9, с. 338]. Просвіта ж офіційно тлумачилась як: «1) поширення знань, освіти; 2) система виховно-освітніх і культурно-просвітницьких закладів в країні» [9, с. 1082] 3 обов'язковим посиданням на статтю про народну освіту того самого видання, яке тлумачить народну освіту (синонім - народна просвіта) як «систему освітньовиховних та культурно-просвітницьких заходів та закладів в країни. За структурою

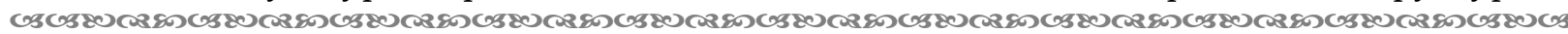


і цілями має історично конкретний характер, залежить від рівня економічного, політичного і культурного розвитку суспільства...» [9, с. 871].

Визначення уможливлюють розуміння сутності та основних аспектів реалізації просвітницьких заходів із цивільної оборони. Актуалізуємо вітчизняний досвід їх здійснення серед населення, зокрема на курсах 3 цивільної оборони.

Наказом начальника цивільної оборони СРСР - заступника міністра оборони СРСР від 30.12.1979 № 148 уведено в дію оновлене Положення про курси цивільної оборони [5], яким визначалось, що курси цивільної оборони є постійно діючими навчальними установами цивільної оборони СРСР, які створюються в республіках, краях, областях, автономних округах, районах, містах рішеннями відповідних рад [5] i їх призначення передбачає підготовку і перепідготовку керівного і командного складу цивільної оборони, фахівців господарства країни, які виконують обов'язки з Ц.О.; вдосконалення і поглиблення знань 3 теорії цивільної оборони та формування практичних навичок щодо якісного проведення відповідних заходів; вивчення змісту, форм і методів морадьно-політичної та психологічної підготовки особистого скдаду сил цивільної оборони і наседення країни; надання методичної допомоги керівництву об'єктів господарства країни в організації та проведенні тактико-спеціальних, командноштабних і комплексних навчань цивільної оборони [5, с. 5-6] у тісній взаємодії 3 ДОСААФ (з рос. - Добровільне товариство сприяння армії, авіації і флоту) шляхом надання матеріально-технічної бази, надання методичної допомоги навчальним пунктам щодо створення відповідних класів (стендів), кваліфікованих викладачів і майстрів виробничого навчання для проведення занять на центральних і зональних курсах [там само, с. 6]. Положення зобов'язувало республіканські, крайові та обласні курси надавати постійну методичну допомогу районним і міським курсам як центрам навчальної і методичної роботи 3 цивільної оборони шляхом систематичного проведення спільних методичних нарад, інструкторсько-методичних занять, демонстраційних та відкритих уроків, взаємних відвідувань занять тощо [там само, c. 6-7].

Положенням чітко регламентовано постійний склад та обов'язки посадових осіб (Розділ 2); комплектування слухачів (Розділ 3); навчальну роботу (Розділ 4); методичну роботу (Розділ 5); підготовку та підвищення кваліфікації викладачів і майстрів виробничого навчання (Розділ 6); навчально-матеріальну базу і фінансування курсів (Розділ 7); визначало добір, розстановку та підготовку постійного складу курсів; комплектацію курсів; контроль за організацією навчального процесу та забезпечення повного виконання навчальних планів і програм; керівництво виховним процесом; заходи із матеріально-технічного забезпечення курсів; контроль за діяльністю тощо [5].

На виконання різних напрямів діяльності, окреслених у Положенні, в усіх регіонах, спрямовано методичні рекомендації та розробки (затверджені обласними / республіканськими / крайовими штабами Ц.О.); рекомендації щодо проведення окремих заходів; програми пришвидшеної підготовки тощо. У контексті актуалізації досвіду освітньо-просвітницької діяльності з цивільної оборони окреслимо основні положення Програми пришвидшеної підготовки робітників, колгоспників та службовців до захисту від зброї масового ураження [7], оскільки саме такі документи окреслюють специфіку просвітницької діяльності.

Програма покликана в короткі терміни підготувати робітників, колгоспників та службовців до практичних дій на основі раніше набутих знань та навичок з окремих питань цивільної оборони. Наголосимо, що усі інструкторсько-методичні заняття із затверджених тем супроводжуються практичним відпрацюванням, під час яких слухачі набувають навичок для підготовки наявних захисних споруд до прийняття населення, побудови найпростіших укриттів, виконанню протипожежних та інших заходів тощо. Для навчання прийомам надання самопомочі та взаємодопомоги запрошують лікарів, фельдшерів, медичних сестер, організовуються бригади санітарних

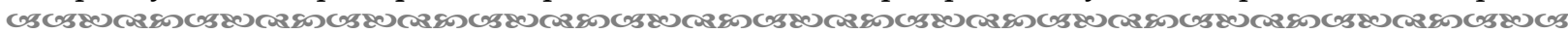
198 
дружинниць. Програмою чітко регламентовано програмні результати навчання та здійснення контрольних заходів [7, с. 3-4].

Програма пришвидшеної підготовки розрахована на такий перелік тем: Підготовка захисних споруд та загдиблених приміщень до прийому населення; Дії за сигналами оповіщення цивільної оборони; Користування засобами індивідуального захисту органів дихання; Підготовка до розосередження й евакуації; Виконання протипожежних заходів; Захист продуктів харчування і води від радіоактивного, хімічного і бактеріологічного зараження; Захист сільськогосподарських тварин і фуражу від радіоактивного, хімічного і бактеріологічного зараження (тема вивчається в сільській місцевості); Здійснення самопомочі і взаємодопомоги в зонах ураження; Знезараження та часткова санітарна обробка [там само, с. 5]. Зазначимо, що кожна тема передбачає не лише перелік питань для опрацювання, а й супроводжуеться методичними вказівками, що значно допомагає керівнику групи у проведенні занять та умождивдює стандартизацію їх проведення в різних регіонах країни. Особливий наголос робиться на тому, що кожен слухач відпрацьовуе практичні навички разом із засвоєнням теоретичної інформації та має мождивість користуватися необхідним матеріадьним забезпеченням, наявність та поставка якого контролюється й забезпечується штабами цивільної оборони, підприємствами тощо.

Однією з ефективних форм навчання керівного складу, невоєнізованих формувань, робітників та службовців, студентів та учнів, населення, не зайнятого у сферах виробництва та обслуговування, є комплексні об'єктові тренування з цивільної оборони. Рекомендаціями 3 підготовки та проведення об'єктових тренувань 3 цивільної оборони окреслено не лише загальні положення (періодичність і тривалість, комплекс заходів, склад груп, перелік і обсяг заходів, відповідальність тощо), значну увагу приділено підготовці об'єктового тренування 3 детальним описом різних періодів: зокрема, у підготовчий період із керівним складом проводидись інструктивні заняття, під час яких уточнювалися порядок проведення тренування, обсяг і послідовність виконання навчальних заходів, заходи безпеки, обсяг та регіони імітації, питання матеріальнотехнічного забезпечення та організація взаємодії між структурними підрозділами, невоєнізованими формуваннями, сусідніми об'єктами; рекогносцировка місць навчання. Під час об'єктного тренування заходи з цивільної оборони проводилися на території підприємств, закладів та установ із максимальним використанням навчальноматеріальної бази ЦО об'єкта; виробнича (навчальна) діяльність не припинялася, а відпрацювання заходів цивільної оборони відбувалося у зручний для конкретного об'єкта час. Конкретизовано заходи тренувань: 3 керівним складом ЦО; з особовим складом невоєнізованих формувань; 3 керівниками та службовцями; 3 населенням відомчого житлового сектора, не занятого в сферах виробництва та обслуговування [8, с. 5-10]. Звернемо увагу на додатки, які несуть інструктивнометодичне навантаження, зокрема, конкретизація констатувальної та розпорядчої частин наказу начальника цивільної оборони конкретного об'єкта про підготовку та проведення об'єктного тренування 3 цивільної оборони; плани-схеми заходів об'єктного тренування 3 цивільної оборони; критерії оцінювання перевірочних дій (заходів) із окресленням конкретних складових та конкретизацією, на чому варто акцентувати увагу [там само, с. 11-18]. Така деталізація дій, доступне й чітке роз'яснення послідовності, мети й очікуваних результатів, опис критеріїв оцінювання забезпечувади ефективність проведення заходів об'єктного тренування 3 цивільної оборони на різних об'єктах господарства країни та сприяли розумінню й усвідомленню значущості відповідних заходів, оскільки визначали якість їх проведення.

Заслуговують на увагу й методичні напрацювання щодо роботи 3 окремою категорією населення «не зайнятого на виробництві та сфері обслуговування», розроблені для керівного складу ЦО [4]. Методична розробка окреслювала перелік літератури для опрацювання, матеріадьно-технічного забезпечення занять; тезовий

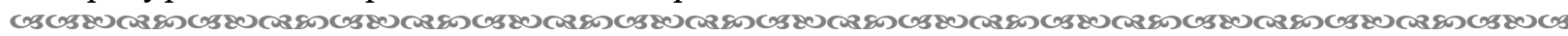


виклад основних теоретичних та методичних питань, якими визначадись програми навчання, відповідальність за організацію i проведення занять, специфіка комплектування груп у сільській і міській місцевостях, розклад занять, місця проведення занять із залученням об'єктів цивільної оборони, автоклубів, інших об'єктів господарства; методи навчання населення, методичний та наочний супровід, очікувані резудьтати навчання відповідно до вікових характеристик та ступеня інвалідності [4, с. 5-9]. Значну увагу приділено психологічній готовності населення з метою запобігання ситуаціям, коли переживання трансформуеться в страх чи паніку. Наголошувалось, що «моральний фактор - це найбільш активний бік духовних сил суспільства, моральний потенціал в дії, сукупність духовних якостей народу, ступінь розуміння людьми тих цілей і завдань, в ім'я яких вони діють...» [там само, с. 10].

Спеціальна підготовка невоєнізованих формувань цивільної оборони регламентувалася Програмою спеціальної підготовки невоєнізованих формувань цивільної оборони на об'єктах народного господарства (1985) [6]. Зміст програми визначав перелік і зміст тем та розрахунок годин зі спеціальної підготовки командирів (керівників) [там само, с. 7-53] та рядового складу [там само, с. 54-96] формувань і містив організаційно-методичні вказівки. Організаційно-методичними вказівками регламентовано, що програма розрахована на три роки та має на меті підготовку формувань до злагоджених дій в зонах ураження, районах стихійних дих, крупних аварій і катастроф. Визначалася відповідальність за підготовку та очікувані ії результати, зокрема знання та вміння командно-керівного і рядового складу формувань [там само, c. 3-5]; особливості загальної і спеціальної підготовки та тактико-спеціальних навчань [там само, с. 5-6].

Одним зі значущим аспектів заходів цивільної оборони є організація та проведення військово-спортивних та воєнізованих заходів із різновіковими категоріями населення, для яких укладалися методичні розробки на кшталт «Організація і методика проведення воєнізованих походів і військово-спортивних ігор 3 відпрацюванням заходів цивільної оборони» [3]. Зазначені розробки окреслювали цілі, час, методи та місце проведення занять; містили перелік питань для опрацювання, визначали необхідне матеріальне забезпечення, перелік навчальної дітератури та організаційно-методичні вказівки. Зауважимо, що організаційно-методичні вказівки значною мірою сприяли покращенню якості проведення занять та формуванню у слухачів відповідних знань і навичок через акцентування уваги слухачів на змістовій та практико-орієнтованих компонентах заходів.

Ідеологічна та морально-політична складова занять із цивільної оборони посідала значне місце у змістовому і практико-орієнтувальному контенті навчальних занять та об'єктних тренувань із цивільної оборони впродовж усього часу існування системи (3 50-х років ХХ століття до руйнування СРСР).

Висновки. Отже, відзначимо регулярність заходів із цивільної оборони як просвітницького, так і практико-орієнтованого характеру. 80-і роки XX століття відзначидись певним оновленням Програм та методичних вказівок і рекомендацій щодо проведення заходів із цивільної оборони серед усіх категорій населення. Як безумовний позитив зазначимо розповсюдження видань із цивільної оборони всіма державними установами та обов' язковість опанування їх змісту й участі у навчаннях та тренувальних заходах, походах і курсах. Спеціальними рекомендаціями регламентувалася специфіка проведення навчально-тренувальних занять та особливості виконання нормативів для різних категорій населення (учнів, студентів, працюючого населення в сільській та міській місцевостях, непрацюючого населення (пенсіонерів, інвалідів та ін.)). Заходи 3 цивільної оборони передбачади заходи із забезпечення психологічної готовності населення до дій в ситуаціях агресивного нападу, катастроф, аварій тощо. Зазначене забезпечувало злагодженість дій населення в непередбачуваних ситуаціях або ситуаціях 
невизначеності, що було би надзвичайно доцільно забезпечити і в сучасних складних умовах нестабільності в усіх сферах життедіяльності.

Перспективами подальших досліджень визначаємо окреслення передумов розгортання системи (мережі) державних заходів із цивільної оборони у 50-60-х роках XX століття.

\section{Список використаних джерел:}

1. Богданов Є. П. Підготовка фахівців цивільного захисту в Україні в контексті формування їх професійної готовності. Педагогічний альманах: збірник наукових праць / редкол. В. В. Кузьменко (голова) та ін. Херсон: КВНЗ «Херсонська академія неперервної освіти», 2019. Випуск 44. С. 101-106.

2. Богданов Є. П. Просвітницька діяльність з питань цивільної оборони в закдадах освіти України (70-80-і роки XX століття). Вісник Національного університету «Чернігівський колегіум» імені Т. Г. Шевченка. Серія: Педагогічні науки. 2020. Вип. 11 (167). С. 172-175.

3. Методическая разработка. Тема 3.20 «Организация и методика проведения военизированных походов и военноспортивных игр с отработкой мероприятий гражданской обороны». 1984.28 с.

4. Методическая разработка дия проведения группового занятия на курсах гражданской обороны с руководящим составом ГО. Тема 1.32 «Организация обучения населения, не занятого в производстве и сфере обслуживания». Павлодар, 1983. 17 с.

5. Приказ начальника гражданской обороны СССР - заместителя министра обороны СССР № 14830 декабря 1979 г. Положение о курсах гражданской обороны. Москва, 1980. 35 с.

6. Программа специальной подготовки невоенизированных формирований гражданской обороны на объектах народного хозяйства. Москва: Военное издательство, 1985. 102 с.

7. Программа ускоренной подготовки рабочих, колхозников и служащих к защите от оружия массового поражения. Москва, 1984. 13 с.

8. Рекомендации по подготовке и проведению объектовых тренировок по гражданской обороне. Гражданская оборона СРСР. Москва, 1989. 18 с.

9. Советский энцикдопедический словарь. Москва: Советская энцикдопедия, 1989. 1600 с.

\section{References:}

1. Bohdanov, Ye. P. (2019). Pidhotovka fakhivtsiv tsyvilnoho zakhystu v Ukraini v konteksti formuvannia yikh profesiinoi hotovnosti [Training of civil defense specialists in Ukraine in the context of forming their professional readiness]. Pedahohichnyi almanakh, 44, 101-106 [in Ukrainian].

2. Bohdanov, Ye. P. (2020). Prosvitnytska diialnist $\mathrm{z}$ pytan tsyvilnoi oborony $\mathrm{v}$ zakladakh osvity Ukrainy (70-80-i roky XX stolittia) [Educational activities on civil defense in educational institutions of Ukraine (70-80s of the XXth century)]. Visnyk Natsionalnoho universytetu «Chernihivskyi kolehium» imeni T. H. Shevchenka. Seriia: Pedahohichni nauky, 11 (167), 172-175 [in Ukrainian].

3. Metodicheskaya razrabotka [Methodical development]. (1984). Tema 3.20 «Organizatsiya i metodika provedeniya voyenizirovannykh pokhodov i voyennosportivnykh igr s otrabotkoy meropriyatiy grazhdanskoy oborony» [Topic 3.20 "Organization and methods of conducting paramilitary campaigns and military sports games with the development of civil defence measures"]. [in Russian].

4. Metodicheskaya razrabotka dlya provedeniya gruppovogo zanyatiya na kursakh grazhdanskoy oborony s rukovodyashchim sostavom GO [Methodological development for conducting a group lesson in civil defense courses with the leadership of the civil defense]. (1983). Tema 1.32 «Organizatsiya obucheniya naseleniya, ne zanyatogo v proizvodstve i sfere obsluzhivaniya» [Topic 1.32 "Organization of training for the population not employed in production and the service sector"]. Pavlodar [in Russian].

5. Regulations on the courses of civil protection, Order of the Chief of Civil Protection of the USSR Deputy Minister of Defense of the USSR No 148 dated December 30, 1979. (1980). Moskva [in Russian].

6. Programma spetcialnoi podgotovki nevoenizirovannykh formirovanii grazhdanskoi oborony na obektakh narodnogo khoziaistva [The program of special training of non-military civil defense units at the facilities of the national economy]. (1985). Moskva: Voennoe izdatelstvo [in Russian]. 
7. Programma uskorennoi podgotovki rabochikh, kolkhoznikov i sluzhashchikh $\mathrm{k}$ zashchite ot oruzhiia massovogo porazheniia [The program of accelerated training of workers, collective farmers and employees for protection against weapons of mass destruction]. (1984). Moskva [in Russian].

8. Rekomendatcii po podgotovke i provedeniiu obektovykh trenirovok po grazhdanskoi oborone [Recommendations for the preparation and conduct of object training in civil protection]. (1989). Moskva [in Russian].

9. Sovetskiy entsiklopedicheskiy slovar [Soviet encyclopedic dictionary]. (1989). Moskva [in Russian].

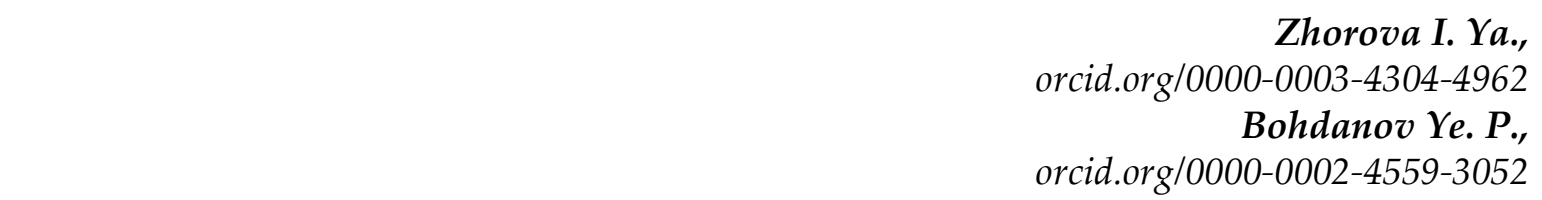

\section{ORGANIZATIONAL AND METHODOLOGICAL SUPPORT OF CIVIL DEFENSE ADVOCACY IN THE 80S OF THE XX CENTURY}

The article provides a content analysis of the main documents of the 80s of the 20th century in the field of civil defense in the USSR, which contributed to the implementation of educational activities among the population (except for educational institutions).

Emphasis is placed on the publications of the 80s of the 20th century, approved by the Ministry of Defense (MD) of the USSR and the Civil Defense (CD) of the USSR (Regulations on Civil Defense Courses; Comprehensive training of civil defense at the national economic assets; Programs on accelerated training of workers, collective farmers and employees for protection against weapons of mass destruction; Programs on special training of non-military troops of civil defense at the facilities of the national economic assets, Instructions, etc.); Command staffs of civil defense of the republics (Recommendations on the training and conduct of asserts training in civil defense; Methodological instructive regulations on the approved list of topics, etc.), regions (Methodological instructive regulations on the conducting group classes in civil defense with the leadership of the central office of $C D$ (organization of the population's training not involved in the production and service spheres), Recommendations on conducting review contests, etc.); manuals such as "Organization and methods of conducting civil defense classes with commanders of intelligence troops", "Civil Defense", "Civil Defense (Methodological instructive regulations to a set of training posters)", etc. It is noted that civil defense publications were distributed by all state institutions, and their content was mandatory for the population of the state to acquire, in contrast to today.

Each topic in civil defense provided not only a list of issues to be processed, but was accompanied by methodological instructive regulations, which assisted the team leader in conducting classes and made it possible to standardize their conduct in different regions of the country. It is emphasized that each student develops practical skills together with the acquiring of theoretical information and has the opportunity to use the necessary material support.

Thus, the purpose of the article was achieved - the actualization of the national experience of educational activities among the population (except for students) in civil defense in the 80s of the 20th century.

Key words: Civil Defense, educational activities, civil defense courses, training programs, methodical regulations. 